\section{Influence of Dietary Protein Levels on the Fate of Inorganic Mercury in Mice}

\author{
Tatsumi Adachi, ${ }^{*}, a, b$ Masaaki Nagano, ${ }^{a}$ \\ Tsukasa Ebihara, ${ }^{b}$ Tsubasa Imai, ${ }^{b}$ \\ Masatake Fujimura, ${ }^{a}$ and Yasunobu Suketa ${ }^{c}$
}

\begin{abstract}
${ }^{a}$ Department of Basic Medical Sciences, National Institute for Minamata Disease, 4058-18 Hama, Minamata, Kumamoto 867-0008, Japan, ${ }^{b}$ Faculty of Pharmacy, Chiba Institute of Science, 15-8 Shiomi-cho, Choshi, Chiba 288-0025, Japan, and ${ }^{c}$ Chiba Institute of Science, 3 Shiomi-cho, Choshi, Chiba 2880025, Japan
\end{abstract}

(Received August 24, 2007; Accepted January 8, 2008; Published online January 9, 2008)

Influence of dietary protein levels on mercury (Hg) fate and on tissue metallothionein (MT) levels was investigated in mice. Twenty-four hr after single administration of mercuric chloride $(2.5 \mathrm{mg} \mathrm{Hg} / \mathrm{kg}$, subcutaneous), the hepatic Hg concentration was enhanced by dietary protein deficiency, whereas the levels in other tissues and excrements were not affected. At that time, MT inductions by mercuric chloride in liver and kidney were suppressed by dietary protein deficiency, despite no observable differences in basal levels. Thus, Hg levels in the liver and kidney showed little correlation with MT levels. A further experiment demonstrated an enhancement of $\mathrm{Hg}$ concentration in the liver by dietary protein deficiency at 3 and $12 \mathrm{hr}$ but not at $1 \mathrm{hr}$, and the $\mathrm{Hg}$ concentration in the kidney was transiently enhanced at $3 \mathrm{hr}$. Accordingly, the differences in $\mathrm{Hg}$ fate would arise considerably earlier, probably before MT induction. The present results suggest that dietary protein status modifies the fate of inorganic $\mathrm{Hg}$, especially in the liver, probably independent of the differences in dietary protein level-dependent varying levels of MT.

Key words — dietary protein, mercuric chloride, metallothionein

\section{INTRODUCTION}

Mercury $(\mathrm{Hg})$ compounds are major environmental pollutants as well as representative hazardous metals. In these compounds, methylmercury $(\mathrm{MeHg})$ and mercuric ion $\left(\mathrm{Hg}^{2+}\right)$ have a high affinity for the thiol group. ${ }^{1-4)}$ Therefore, thiol compounds such as glutathione (GSH), an ubiquitous thiol-containing tripeptide, and metallothionein (MT), a cysteine-rich low molecular weight protein, play important roles in the fate and toxicity of these compounds. ${ }^{2-11)}$

We have revealed that dietary levels of protein and sulfur amino acids are an important factor on the fate and toxicity of $\mathrm{MeHg}$ using rodents fed on a $24.8 \%$ protein diet (normal protein diet, NPD), a $7.5 \%$ protein diet (low protein diet, LPD) or either diet supplemented with sulfur amino acids. ${ }^{12-18)}$ In these experiments, the dietary modifications markedly altered the metabolism of low molecular weight thiol compounds including $\mathrm{GSH},{ }^{12,13,19,20)}$ and the alterations have been suggested to be one reason for the marked differences in the fate of $\mathrm{MeHg}$. In contrast, there are only a few reports revealing the influence of nutritional conditions such as dietary protein deficiency on the fate and toxicity of $\mathrm{Hg}^{2+}$. For example, it is reported that feeding of protein-free diet could reduce the nephrotoxicity of $\mathrm{Hg}^{2+}$, and demonstrated indirectly using $\mathrm{ZnSO}_{4}$ that the reduction might result from suppressed MT induction caused by the diet. ${ }^{21)}$ However, in that study, whether dietary protein levels affect $\mathrm{Hg}$ accumulation as well as the metabolism of MT including basal and $\mathrm{Hg}^{2+}$-induced levels remains unclear, although it is well known that MT plays important roles in retention of $\mathrm{Hg}^{2+}$ as well as protection against its acute nephrotoxicity. ${ }^{10)}$ Therefore, the relationship between $\mathrm{Hg}$ fate and MT metabolism must be further elucidated under several nutritional conditions such as dietary protein deficiency.

In the present study, mice fed on NPD or LPD were singly administered $\mathrm{Hg}^{2+}$, and tissue distribution and excretion of $\mathrm{Hg}$ and tissue MT levels were examined. The results were then discussed as to whether or not differences in the fate of inorganic $\mathrm{Hg}$ were caused by variation of MT levels after the administration.

\footnotetext{
*To whom correspondence should be addressed: Faculty of Pharmacy, Chiba Institute of Science, 15-8 Shiomi-cho, Choshi, Chiba 288-0025, Japan. Tel.: +81-479-30-4684; Fax: +81-479-30-4740; E-mail: tadachi@cis.ac.jp
} 


\section{MATERIALS AND METHODS}

Animals - C57BL/6N male mice (aged 7 weeks) were obtained from CLEA Japan Co. (Osaka, Japan). The animals were maintained at $23 \pm 2{ }^{\circ} \mathrm{C}$ and $50-60 \%$ relative humidity and were exposed to a 12-hr light cycle from 7:00 a.m. They were housed individually, and fed on each of the two casein-based diets, NPD or LPD (CLEA Japan Co.), for 5 days before administration of $\mathrm{Hg}^{2+}$ or saline. The composition of the diets was reported previously. ${ }^{12)}$ All had free access to diet and tap water throughout the experiment. All experimental procedures were approved by the Ethics Committee on Animal Experiments of the National Institute for Minamata Disease (NIMD).

Treatment - Mercuric chloride (Wako Pure Chemical Industries, Osaka, Japan) was dissolved in saline and subcutaneously administered to mice at a dose of $2.5 \mathrm{mg} \mathrm{Hg} / \mathrm{kg}$. Control groups of mice were administered saline at that time. The animals were then housed in metabolism cages (1 mouse/cage). Twenty-four hr after the administration, urine and feces were collected and each mouse was anesthetized using pentobarbital. Blood was collected from the inferior caval vein in a heparinized syringe, and an aliquot of blood was centrifuged at $3000 \mathrm{rpm}$ for $3 \mathrm{~min}$ to separate plasma. After blood was removed from tissues by perfusion with ice-cold saline via the heart, the kidney and liver were excised. To examine time-dependent alterations in tissue $\mathrm{Hg}$ concentrations, tissues of another group of mice were obtained as described above 1,3 and $12 \mathrm{hr}$ after subcutaneous administration of mercuric chloride $(2.5 \mathrm{mg} \mathrm{Hg} / \mathrm{kg})$. At least within $24 \mathrm{hr}$ after the administration, the plasma creatinine concentration (an index of nephrotoxicity) and plasma alanine aminotransferase activity (an index of hepatotoxicity), determined as previously described, ${ }^{14,15)}$ were not increased by the administration of $\mathrm{Hg}^{2+}$ compared with those in salineadministered control mice in either dietary group (data not shown), suggesting that little damage in the liver and kidney was caused by that dose of $\mathrm{Hg}^{2+}$.

Analyses of MT and $\mathbf{H g}-\mathrm{MT}$ levels in the liver and kidney were determined using the $\mathrm{Hg}$ binding method ${ }^{22)}$ with modifications. Tissue homogenate in $1.15 \% \mathrm{KCl}$ (approximately $5 \% ; 1.0 \mathrm{ml}$ ) was mixed with diethylmaleate $(5 \mu \mathrm{l})$ and incubated at room temperature for $15 \mathrm{~min}$. After an addition of $10 \mathrm{mM}$ cadmium chloride $(25 \mu \mathrm{l})$, the samples were heated at $100^{\circ} \mathrm{C}$ for $5 \mathrm{~min}$ and centrifuged at $2000 \mathrm{rpm}$ for $15 \mathrm{~min}$. Mercuric chloride $(5 \mathrm{mM}$; $25 \mu \mathrm{l})$ was added to the supernatant $(0.5 \mathrm{ml})$, and MT-unbound $\mathrm{Hg}$ was removed by adding $1 \mathrm{mM}$ ovalbumin $(225 \mu \mathrm{l})$ followed by deproteinizing with $12.5 \%$ trichloroacetic acid $(250 \mu \mathrm{l})$. After centrifugation at $8000 \mathrm{rpm}$ for $5 \mathrm{~min}$, the obtained supernatant was filtered using a $0.22 \mu \mathrm{m}$ Millipore filter. The $\mathrm{Hg}$ amount in each filtrate (MT-bound $\mathrm{Hg}$ ) was measured by the oxygen combustion-gold amalgamation method ${ }^{23)}$ using a Rigaku Mercury Analyzer SP-3 or MA2 (Nippon Instruments Co., Tokyo, Japan). MT levels were calculated based on a binding ratio of MT to metals of $1: 7$. Hg contents in the liver, kidney, blood, plasma and excrements were determined by the oxygen combustiongold amalgamation method ${ }^{23)}$ as indicated above.

Statistical Analysis — Significant differences between individual means were determined by oneway analysis of variance followed by Duncan's new multiple range test or Student's $t$-test. Differences were considered significant at $p<0.05$.

\section{RESULTS AND DISCUSSION}

We examined tissue distribution and excretion of $\mathrm{Hg} 24 \mathrm{hr}$ after single administration of $\mathrm{Hg}^{2+}$ ( $2.5 \mathrm{mg} \mathrm{Hg} / \mathrm{kg}$, subcutaneous) in mice fed NPD or LPD. $\mathrm{Hg}$ concentration in liver was approximately 1.7 times higher in LPD-fed mice than in NPDfed mice (Table 1). In contrast, $\mathrm{Hg}$ concentration in kidney, a major tissue to which inorganic $\mathrm{Hg}$

Table 1. Influence of Dietary Protein Levels on Tissue and Excretory $\mathrm{Hg}$ Levels $24 \mathrm{hr}$ after Administration of $\mathrm{Hg}^{2+}$

\begin{tabular}{llrr}
\hline \hline & & \multicolumn{2}{c}{ Diet } \\
\cline { 3 - 4 } & & \multicolumn{1}{c}{ NPD } & \multicolumn{1}{c}{ LPD } \\
\hline Liver & $(\mu \mathrm{g} / \mathrm{g})$ & $1.27 \pm 0.22$ & $2.19 \pm 0.40^{*}$ \\
& $(\%$ of dosed $\mathrm{Hg})$ & $2.50 \pm 0.42$ & $3.76 \pm 0.54^{*}$ \\
Kidney & $(\mu \mathrm{g} / \mathrm{g})$ & $35.59 \pm 6.02$ & $39.10 \pm 0.53$ \\
& $(\%$ of dosed $\mathrm{Hg})$ & $23.05 \pm 4.03$ & $22.34 \pm 0.07$ \\
Blood & $(\mu \mathrm{g} / \mathrm{ml})$ & $0.30 \pm 0.01$ & $0.31 \pm 0.01$ \\
Plasma & $(\mu \mathrm{g} / \mathrm{ml})$ & $0.45 \pm 0.03$ & $0.50 \pm 0.06$ \\
Urine & $(\%$ of dosed $\mathrm{Hg})$ & $38.53 \pm 3.85$ & $36.50 \pm 0.85$ \\
Feces & $(\%$ of dosed $\mathrm{Hg})$ & $3.35 \pm 0.55$ & $4.97 \pm 1.43$ \\
\hline
\end{tabular}

Mice were subcutaneously administered mercuric chloride $(2.5 \mathrm{mg} \mathrm{Hg} / \mathrm{kg}$ ). Values represent the mean \pm S.D. obtained from 3 to 4 mice. $\left(^{*}\right)$ indicates significant difference from NPD-fed mice at $p<0.05$. The ratio of tissue weights to body weight in NPD- and LPD-fed mice were $0.0494 \pm 0.0018$ and $0.0438 \pm 0.0021$ in the liver, and $0.0162 \pm 0.0005$ and $0.0145 \pm 0.0002$ in the kidney, respectively. 
distributed, ${ }^{3)}$ was similar in the two dietary groups (Table 1). The ratio of the weight of either the liver or kidney to body weight was significantly lower in LPD-fed mice than in NPD-fed mice (footnote to Table 1), since the weights in both tissues were lower in LPD-fed mice and there was no significant difference in the body weight (data not shown), as previously reported. ${ }^{12,13,18)}$ However, the difference in the percentage of accumulated $\mathrm{Hg}$ between the dietary groups showed the same trend as the $\mathrm{Hg}$ concentration in each tissue (Table 1). No significant differences were observed in $\mathrm{Hg}$ levels in blood, plasma, urine and feces (Table 1).

Influence of dietary protein levels and $\mathrm{Hg}^{2+}$ on tissue MT levels was determined, since it is well known that MT affects the retention of $\mathrm{Hg}^{2+} .3,10$ ) In saline-administered control mice, MT concentrations in liver and kidney were similar in NPDand LPD-fed mice (Fig. 1). Twenty-four hr af-
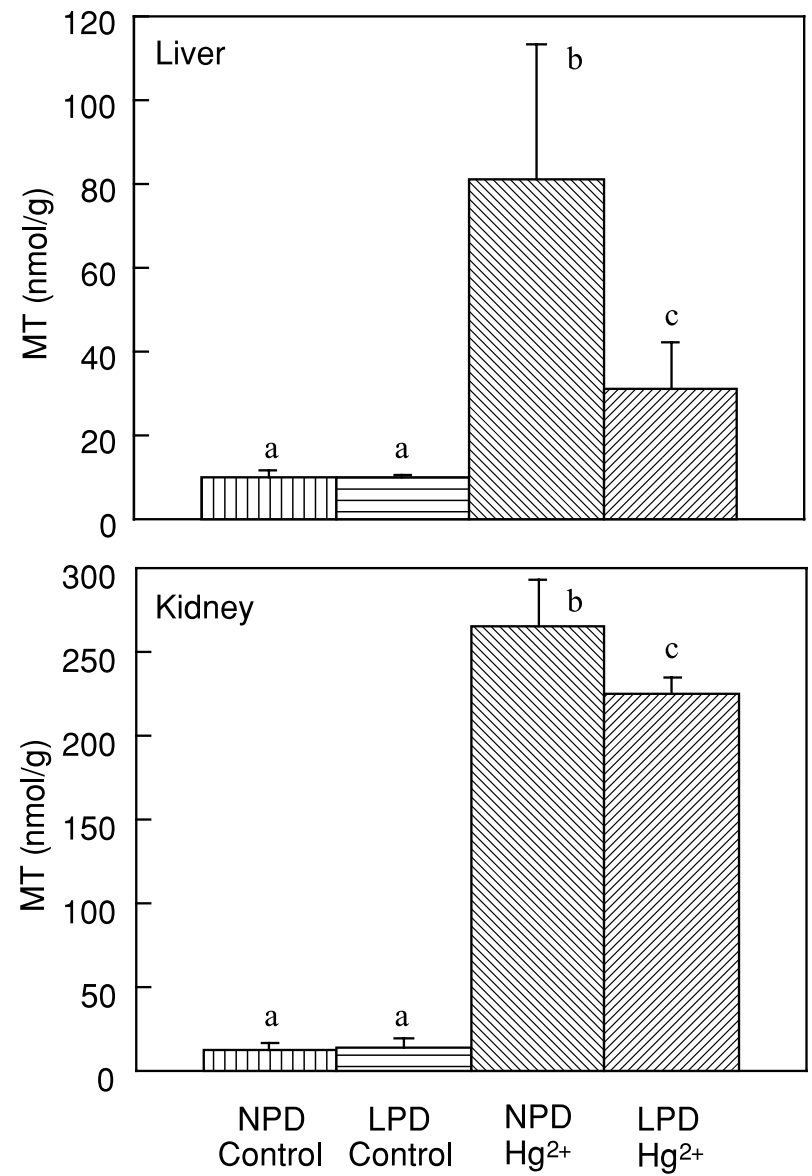

Fig. 1. Influence of Dietary Protein Levels on Tissue MT Levels in Mice $24 \mathrm{hr}$ after Administration of $\mathrm{Hg}^{2+}$ or Saline

Mice were subcutaneously administered mercuric chloride $(2.5 \mathrm{mg} \mathrm{Hg} / \mathrm{kg}$ ) or saline (controls). Values represent the mean \pm S.D. obtained from 3 to 4 mice. Values with different superscripts (a-c) are significantly different $(p<0.05)$. ter the $\mathrm{Hg}^{2+}$ administration, MT concentrations in NPD- and LPD-fed mice were approximately 8 and 3 times higher in the liver, and were approximately 19 and 15 times higher in the kidney compared to the respective controls (Fig. 1), suggesting that MT inductions by $\mathrm{Hg}^{2+}$ in these tissues are less when the dietary protein level is deficient than when it is adequate. As a result, the MT levels in both tissues in $\mathrm{Hg}^{2+}$-administered mice were significantly lower in LPD-fed mice than in NPD-fed mice (Fig. 1). These results indicate that LPD-fed mice show a higher hepatic $\mathrm{Hg}$ level and a similar renal level compared to NPD-fed mice $24 \mathrm{hr}$ after $\mathrm{Hg}^{2+}$ administration (Table 1), despite lower MT concentrations in both tissues at that time (Fig. 1). The mole ratio of $\mathrm{Hg}$ to MT calculated in both tissues was less than 1 regardless of the kind of diet (Table 2), suggesting that MT would be abundantly induced under the conditions in this study. The ratio in the liver was higher in LPD-fed mice than in NPD-fed mice, whereas there was no significant difference in the kidney (Table 2). These results would probably reflect the differences in accumulated $\mathrm{Hg}$ levels in the tissues rather than varying binding activity of MT to $\mathrm{Hg}^{2+}$, given the below-mentioned fact that the differential in $\mathrm{Hg}$ fate between the dietary groups would arise earlier than the MT induction.

It has been reported that most $\mathrm{Hg}$ binds to high molecular weight substrates in cytosol a few hr after administration of inorganic $\mathrm{Hg}$, whereas $\mathrm{Hg}$ binds to MT rather than them $24 \mathrm{hr}$ after. ${ }^{9)}$ Therefore, it is important to clarify from when the differences in tissue $\mathrm{Hg}$ levels are observed between the dietary groups. As shown in Fig. 2, Hg concentrations in liver and kidney were significantly higher in LPDfed mice than in NPD-fed mice at $3 \mathrm{hr}$, although no differences were observed at $1 \mathrm{hr}$. In addition, the difference in the liver remained at $12 \mathrm{hr}$ but disappeared in the kidney (Fig. 2). Hg concentrations in blood and plasma were similar between the dietary groups at all times (data not shown). These results

Table 2. Influence of Dietary Protein Levels on $\mathrm{Hg} / \mathrm{MT}$ Mole Ratio $24 \mathrm{hr}$ after Administration of $\mathrm{Hg}^{2+}$

\begin{tabular}{lcc}
\hline \hline & \multicolumn{2}{c}{ Diet } \\
\cline { 2 - 3 } & NPD & LPD \\
\hline Liver & $0.082 \pm 0.016$ & $0.384 \pm 0.143^{*}$ \\
Kidney & $0.676 \pm 0.127$ & $0.868 \pm 0.035$ \\
\hline
\end{tabular}

Mice were subcutaneously administered mercuric chloride $(2.5 \mathrm{mg} \mathrm{Hg} / \mathrm{kg})$. Values represent the mean \pm S.D. obtained from 3 to 4 mice. (*) indicates significant difference from NPD-fed mice at $p<0.05$. 

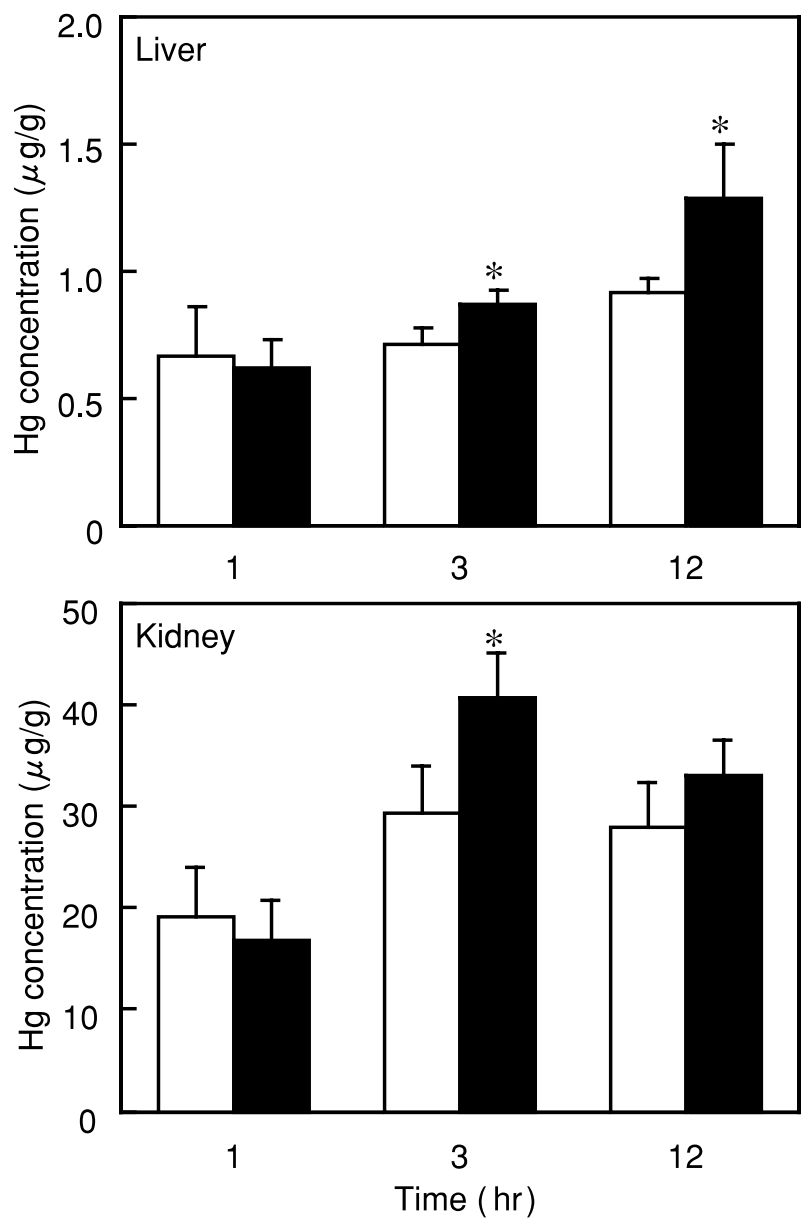

Fig. 2. Time-dependent Alterations in $\mathrm{Hg}$ Concentrations in Liver and Kidney in Mice fed NPD ( $\square$ ) or LPD (ם) after Administration of $\mathrm{Hg}^{2+}$

Mice were subcutaneously administered mercuric chloride $(2.5 \mathrm{mg} \mathrm{Hg} / \mathrm{kg})$. Values represent the mean \pm S.D. obtained from 3 to 5 mice. $(*)$ indicates significant difference from NPD-fed mice at the specified times at $p<0.05$.

suggest that the $\mathrm{Hg}$ level in the liver might continue to be higher in LPD-fed mice than in NPD-fed mice, probably at least from 3 to $24 \mathrm{hr}$, although the difference in the kidney is transient. In addition, the differences in $\mathrm{Hg}$ fate would arise considerably earlier, probably before MT induction. Our present results and the fact that most $\mathrm{Hg}$ binds to high molecular weight ligands rather than MT 2-4 hr after administration of inorganic $\left.\mathrm{Hg},{ }^{9}, 10\right)$ suggest an involvement of factors other than the MT in the dietary protein level-dependent difference in $\mathrm{Hg}$ accumulation.

It has been suggested that GSH, particularly in the liver, plays an important role for the uptake and accumulation of $\mathrm{Hg}^{2+}$ in the kidney. That is, since inorganic $\mathrm{Hg}$ conjugated with GSH is secreted from the liver to plasma, and then transported to the kidney, the suppressed hepatic GSH level in- duces the lower renal Hg level. ${ }^{7,11)}$ We previously found that the GSH concentration in the liver was lower in LPD-fed mice than in NPD-fed mice, but the levels in the kidney, blood and plasma were similar. ${ }^{12,19)}$ Accordingly, LPD-fed mice that have the lower hepatic GSH level should show a lower renal $\mathrm{Hg}$ level than NPD-fed mice. However, that level is in reality similar (Table 1). We previously demonstrated that the efflux rate of GSH from liver was suppressed and the rate from kidney was not affected by dietary protein deficiency, and that this is one reason for the dietary protein level-dependent alterations in the fate of MeHg. ${ }^{12)}$ Since LPD-fed mice, which have a slower efflux rate of GSH from the liver, ${ }^{12)}$ show a higher hepatic Hg level (Table 1) compared to NPD-fed mice, alterations in GSH metabolism might partly account for the differences in the fate of $\mathrm{Hg}^{2+}$. However, the $\mathrm{Hg}$ level in the kidney plus urine was not affected in this study (Table 1), although it was suppressed by dietary protein deficiency in the previous study regarding the fate of MeHg. ${ }^{12,18)}$ Therefore, further detailed study regarding the influx, efflux and retention of $\mathrm{Hg}^{2+}$ in these tissues would be necessary to clarify the reason for the differences in its fate.

The present results suggest that dietary protein levels are an important factor in the fate of inorganic $\mathrm{Hg}$ and in $\mathrm{Hg}^{2+}$-induced MT synthesis. It is also suggested that the alterations in $\mathrm{Hg}$ levels in various tissues caused by nutritional conditions such as dietary protein deficiency might not simply reflect the varying levels of MT induced after a single administration of inorganic $\mathrm{Hg}$, at least in short-term experiments.

Acknowledgments The authors are grateful to Ms. Ryuko Takenoshita-Shimoda (NIMD), Ms Rieko Ochiai (NIMD) and Ms. Akiko Tazoe (NIMD) for their technical assistance.

\section{REFERENCES}

1) Bach, R. D. and Weibel, A. T. (1976) Nuclear magnetic resonance studies on anion-exchange reactions of alkylmercury mercaptides. J. Am. Chem. Soc., 98, 6241-6249.

2) World Health Organization (WHO) (1990) Environmental Health Criteria 101, Methylmercury, WHO, Geneva.

3) World Health Organization (WHO) (1991) Environmental Health Criteria 118, Inorganic Mercury, 
WHO, Geneva.

4) Clarkson, T. W. (1993) Molecular and ionic mimicry of toxic metals. Annu. Rev. Pharmacol. Toxicol., 32, 545-571.

5) Hirayama, K., Yasutake, A. and Inoue, M. (1987) Effect of sex hormones on the fate of methylmercury and on glutathione metabolism in mice. Biochem. Pharmacol., 36, 1919-1924.

6) Naganuma, A., Oda-Urano, N., Tanaka, T. and Imura, N. (1988) Possible role of hepatic glutathione in transport of methylmercury into mouse kidney. Biochem. Pharmacol., 37, 291-296.

7) Tanaka, T., Naganuma, A. and Imura, N. (1990) Role of $\gamma$-glutamyltranspeptidase in renal uptake and toxicity of inorganic mercury in mice. Toxicology, 60, 187-198.

8) Hirayama, K., Yasutake, A. and Adachi, T. (1991) Mechanism for renal handling of methylmercury. In Advances in Mercury Toxicology (Suzuki, T., Imura, N. and Clarkson, T. W., Eds.), Plenum Press, New York, pp.121-134.

9) Tanaka-Kagawa, T., Naganuma, A. and Imura, N. (1992) Tubular secretion and reabsorption of mercury compounds in mouse kidney. J. Pharmacol. Exp. Ther, 264, 776-782.

10) Satoh, M., Nishimura, N., Nakayama, Y., Naganuma, A., Suzuki, T. and Tohyama, C. (1997) Enhanced renal toxicity by inorganic mercury in metallothionein-null mice. J. Pharmacol. Exp. Ther., 283, 1529-1533.

11) Zalups, B. K. (2000) Molecular interactions with mercury in the kidney. Pharmacol. Rev., 52, 113143.

12) Adachi, T., Yasutake, A. and Hirayama, K. (1992) Influence of dietary protein levels on the fate of methylmercury and glutathione metabolism in mice. Toxicology, 72, 17-26.

13) Adachi, T., Yasutake, A. and Hirayama, K. (1994) Influence of dietary levels of protein and sulfur amino acids on the fate of methylmercury in mice. Toxicology, 93, 225-234.

14) Adachi, T., Yasutake, A. and Hirayama, K. (1995)
Influence of dietary levels of protein and sulfur amino acids on the subacute toxicity of methylmercury in mice. Jpn. J. Toxicol. Environ. Health, 41, 411-418.

15) Adachi, T., Yasutake, A., Eto, K. and Hirayama, K. (1996) Influence of dietary protein levels on the acute toxicity of methylmercury in mice. Toxicology, 112, 11-17.

16) Adachi, T. and Hirayama, K. (1998) Dietary protein levels cause different effects of methionine supplement on the fate of methylmercury in mice. Jpn. J. Toxicol. Environ. Health, 44, 226-232.

17) Adachi, T. and Hirayama, K. (2005) Influence of dietary protein levels on the fate of methylmercury and on amino acid transport at the renal brush border membrane in rats. J. Health Sci., 51, 138-146.

18) Adachi, T., Kuwana, T., Pan, H. S. and Hirayama, K. (2005) Sex difference in the influence of dietary protein deficiency on the fate of methylmercury in mice and rats. J. Health Sci., 51, 207-211.

19) Adachi, T., Yasutake, A. and Hirayama, K. (2002) Influence of dietary levels of protein and sulfur amino acids on metabolism of glutathione and related amino acids in mice. J. Health Sci., 48, 446450 .

20) Adachi, T. (2006) Dietary protein level-dependent alterations in urinary excretion of thiol compounds caused by L-methionine supplement in mice. $J$. Health Sci., 52, 63-66.

21) Levine, S. and Saltzman, A. (2003) Acute uremia produced in rats by nephrotoxic chemicals is alleviated by protein deficient diet. Ren. Fail., 25, 517523.

22) Naganuma, A., Satoh, M. and Imura, N. (1987) Prevention of lethal and renal toxicity of cisdiamminedichloroplatinum (II) by induction of metallothionein synthesis without compromising its antitumor activity in mice. Cancer Res., 47, 983-987.

23) Jacobs, M. B., Yamaguchi, S., Goldwater, L. J. and Gilbert, H. (1960) Determination of mercury in blood. Am. Ind. Hyg. Assoc. J., 21, 475-480. 